\title{
THE DYNAMICS OF THE HEXAVALENT CHROMIUM INDUCED APOPTOTIC PATTERNS IN VITRO
}

\author{
Emil Rudolf, Jan Peychl, Miroslav Červinka \\ Charles University in Prague, Faculty of Medicine in Hradec Králové: Department of Medical Biology and Genetics
}

\begin{abstract}
Summary: Although hexavalent chromium has been shown to induce apoptosis in cells cultivated in vitro, there appear to be no studies focusing on the dynamics of this process. To find out about dynamic patterns of hexavalent chromium-induced apoptosis, we treated Hep2 cells with $150 \mu \mathrm{g} / \mathrm{ml}$ potassium chromate and recorded their behavior as well as appearance of some crucial organelles using different morphological and biochemical methods. We found that Hep2 cells showed the earliest observable changes at 6 hours after the treatment (blebbing, chromatin shrinkage), with the entire apoptotic process lasting up to 24 hours. While all the observed cell features clearly prove apoptosis induced by hexavalent chromium, a typical apoptotic hallmark, DNA ladder, seems not to occur in this type of cells. On the other hand, in HL60 cells, used as a control, this ladder was observable.
\end{abstract}

Key words: Potassium chromate; Apoptosis; Morphological methods; DNA ladder; Nuclear changes

\section{Introduction}

Cell death is an important part of the cell cycle. The cell lives, consumes energy, and divides itself repeatedly until a moment when these activities are no longer sustained and the cell dies. Upon this death, it is possible to detect different morphological, biochemical, and molecular features that allow us to distinguish the two basic types of cell death - apoptosis and necrosis. While necrosis and various mechanisms inducing it have long been known and understood, it is the intricate mechanism of apoptosis that remains unresolved and has led scientists to focus on it during the last decades (10).

Apoptosis is defined as programmed cell death, thus, something quite natural and physiological. According to this definition, every eukaryotic cell seems to have an internal genetic program which serves to destroy its bearer when necessary. Its importance is best illustrated by the fact that different pathways and mechanisms of this program are still being identified and every year new facts appear (15).

Apoptosis or apoptosis-like processes are also induced by many external factors, a fact adding to the overall complexity of this phenomena. Although in this case it is problematic to use the definition "programmed cell death," the behavior and appearance of externally treated cells resemble very closely those of naturally dying cells. Since the introduction of apoptosis as one of the fundamental types of cell death, tens of external factors have been reported to be apoptotic inducers. These so called xenobiotics, include many chemicals, drugs, and physical factors, some known to be beneficial, while others known to be harmful to living organisms (2).
This is also the case of hexavalent chromium. While the cytotoxic, genotoxic, and carcinogenic potential of hexavalent chromium $(8,12,14)$ has been known for almost eighty years, its ability to induce apoptosis was not recognized until recently. Several studies published over the last five years $(3,5,13)$ showed that hexavalent chromium compounds caused cells to express the typical apoptotic features: i.e. cell shrinkage, formation of membrane blebs, nucleus and DNA fragmentation and marginalization. Still, the expression of these features in the studied cells is generalized and considered by many universal, despite the growing evidence of possibly varying cell behavior in response to apoptotic stimuli.

How the specific chromium compound interacts with the particular cells is described rather well (initial as well as terminal stages) (13), but the course of its cytotoxic activity leading to apoptosis, especially its dynamic aspects remain relatively unexplored. To find out, we lined up several experiments that would lead us to some of the answers concerning the dynamics of cell death after exposure to potassium chromate, an important environmental xenobiotic not often included in studies.

\section{Materials and Methods}

\section{Materials}

Potassium chromate $-\mathrm{K}_{2} \mathrm{CrO}_{4}$ was purchased from Sigma (Cat. No. P 0454), dissolved in DMEM without serum and kept at low temperature as $1.0 \mathrm{~mol} / 1$ stock solution. 


\section{Cell lines}

Human laryngeal cell line Hep2 (EATCC, Porton Down, England) was maintained as stationary monolayer in plastic tissue-culture dishes (Nunc). Cells were grown in Dulbecco's modified Eagle's medium (Sevapharm, Czech republic) supplemented with $10 \%$ bovine serum (Bioveta Ivanovice, Czech Republic), $100 \mathrm{U} / \mathrm{ml}$ penicillin, and 100 $\mu \mathrm{g} / \mathrm{ml}$ streptomycin. The medium was changed every third day, and cells were passaged using $0.25 \%$ trypsin.

Human leukemia HL-60 cells (EATCC, Porton Down, England) were grown in RPMI 1640 medium (Sevapharma, Czech Republic) supplemented with $10 \%$ fetal calf serum (Gibco, Germany), $100 \mathrm{U} / \mathrm{ml}$ penicillin, and $100 \mu \mathrm{g} / \mathrm{ml}$ streptomycin. Cells were maintained in an incubator at $37^{\circ} \mathrm{C}$ and $5 \% \mathrm{CO}_{2}$ atmosphere and were passaged three times a week to maintain log-phase growth.

\section{Time- lapse video microscopy}

Hep2 cells were grown in Dulbecco's modified Eagle's medium under standard laboratory conditions $\left(37{ }^{\circ} \mathrm{C}, 5 \%\right.$ $\mathrm{CO}_{2}$ ). After 24 hours of cultivation, the standard medium was replaced with a medium containing $150 \mu \mathrm{g} / \mathrm{ml}$ potassium chromate. The culture flask was left in an incubator for 20 minutes and then transferred to a $37^{\circ} \mathrm{C}$ heated chamber where all recordings were done. Hep 2 cells were examined using an inverted microscope Olympus IMT-2 equipped with a long-working-distance condenser, and a $20 \mathrm{x}$ phase contrast lens. For time-lapse recording, the microscope was mounted with a Mitsubishi CCD-100 E camera and connected to a Mitsubishi video recorder HS-S5600. The recording was performed in a 480 mode, with a slowing factor 160. Recording continued for 48 hours, with a subsequent film analysis. At given intervals the behavior of the observed cells was photographed.

\section{WST-1 assay}

Hep 2 cells at concentration $3 \times 10^{4}$ cells $/ \mathrm{ml}$ in $200 \mu 1$ of DMEM medium containing $10 \%$ bovine serum were seeded in two 96 well microtiter plates, always with the first column of wells without cells (blank). The cells were incubated 24 hours at $37{ }^{\circ} \mathrm{C}$ and in $5 \% \mathrm{CO}_{2}$. After incubation, the medium was replaced with the medium containing $150 \mu \mathrm{g} / \mathrm{ml}$ potassium chromate and the cells were treated for 4, 6, 8, 12 and $24 \mathrm{~h}$. After each time interval, $100 \mu \mathrm{g}$ of WST-1 (Boehringer Mannheim-Roche, Cat. No. 1644 807) was added. The cells were further incubated for 2 hours in an incubator. The absorbance was recorded at $450 \mathrm{~nm}$ with $650 \mathrm{~nm}$ of reference wavelength by a scanning multiwell spectrophotometer. In all cases, the absorbance of the tested substance in medium alone was recorded to determine whether it interfered with the assay.

\section{Selective nuclear-fragmentation staining}

Hep2 cells were grown in Dulbecco's modified Eagle's medium under standard laboratory conditions $\left(37^{\circ} \mathrm{C}, 5 \%\right.$ $\mathrm{CO}_{2}$ ). Following 24 hours of cultivation, the cells were exposed to $150 \mu \mathrm{g} / \mathrm{ml}$ potassium chromate for $4,6,8,12$ and 24 hours. After each time interval, the cells were detached with a cell scraper and centrifuged at $68 \mathrm{x} \mathrm{g}$ (JOUAN MR 22 , rotor AM 2.19) for 5 minutes at room temperature. The medium was aspirated, the cell pellet washed with $5 \mathrm{ml}$ PBS, resuspended and prefixed with 5 droplets of a fixative solution (methanol plus acetic acid - 3:1). The cells were centrifuged at $68 \times \mathrm{g}$ (JOUAN MR 22, rotor AM 2.19) for 5 minutes at room temperature and again fixed with $5 \mathrm{ml}$ of the fixative solution. After another centrifugation (the same conditions), the cells were pipetted onto a slide and allowed to dry. The specimens were then briefly washed in distilled water and stained with a Giemsa solution (Sigma, Czech Republic) for 20 minutes.

\section{Quantitation of cell viability and apoptotic index by acridine orange/ethidium bromide uptake}

Hep2 cells were grown in Dulbecco's modified Eagle's medium under standard laboratory conditions $\left(37^{\circ} \mathrm{C}, 5 \%\right.$ $\mathrm{CO}_{2}$ ). Following 24 hours of cultivation, the cells were exposed to $150 \mu \mathrm{g} / \mathrm{ml}$ potassium chromate for 4, 6, 8, 12 and 24 hours. After each time interval, the cells were detached with a cell scraper and centrifuged at $68 \mathrm{x}$ g for 5 minutes at room temperature. The cell suspension was stained with a mix of acridine orange/ethidium bromide (Sigma, Czech Republic) and pipetted onto a clean slide. The specimens were observed under a fluorescence microscope (Fluoval, Jena), magnification 100-400x (excitation filter 450-490 $\mathrm{nm}$, emission $520 \mathrm{~nm}$ ). The results were quantified by cell counting in 100 visual fields.

\section{DNA fragmentation assay}

Hep2 cells were grown in Dulbecco's modified Eagle's medium under standard laboratory conditions $\left(37^{\circ} \mathrm{C}, 5 \%\right.$ $\mathrm{CO}_{2}$ ). After 24 hours of cultivation, the standard medium was replaced with a medium supplemented with potassium chromate in the concentration $150 \mu \mathrm{g} / \mathrm{ml}$ and the cells were exposed to it $6,8,12,16$, and 24 hours. After the treatment, the cells were harvested and resuspended in the medium to the final concentration of approximately $10^{6}$ cell $/ \mathrm{ml}$. Next, the cells were centrifuged for 5 min (JOUAN MR 22, rotor SWM 180.5) at $157 \mathrm{xg}$ at $4{ }^{\circ} \mathrm{C}$. The resulting pellet was resuspended in $0.5 \mathrm{ml}$ sodium azide $(0.1 \%)$, pipetted into 1.5 $\mathrm{ml}$ tubes and again centrifuged for $5 \mathrm{~min}$ (JOUAN MR 22, rotor AM 2.19) at $80 \mathrm{xg}$ at $4{ }^{\circ} \mathrm{C}$. The pellets were stored at - $80{ }^{\circ} \mathrm{C}$. Cell lysis buffer containing $500 \mathrm{mmol} / \mathrm{l}$ Tris- $\mathrm{HCl}$ (pH8), $16 \mathrm{mmol} / 1$ ethylenediamine tetracetic acid (EDTA), $10 \mathrm{mmol} / 1 \mathrm{NaCl}$ plus $10 \mu \mathrm{l}$ proteinase $\mathrm{K}(20 \mathrm{mg} / \mathrm{ml})$ and 20 
$\mu 110 \%$ sodium dodecyl sulphate (SDS) was added to the cells and the whole solution was incubated for 16 hours at $37{ }^{\circ} \mathrm{C}$. The solution was centrifuged for $10 \mathrm{~min}$ (JOUAN MR 22, rotor AM 2.19) at $1,790 \mathrm{x}$ g at $4^{\circ} \mathrm{C}$, supernatant collected, and DNA isolated by phenol/chloroform extraction and ethanol precipitation. Isolated DNA was resuspended
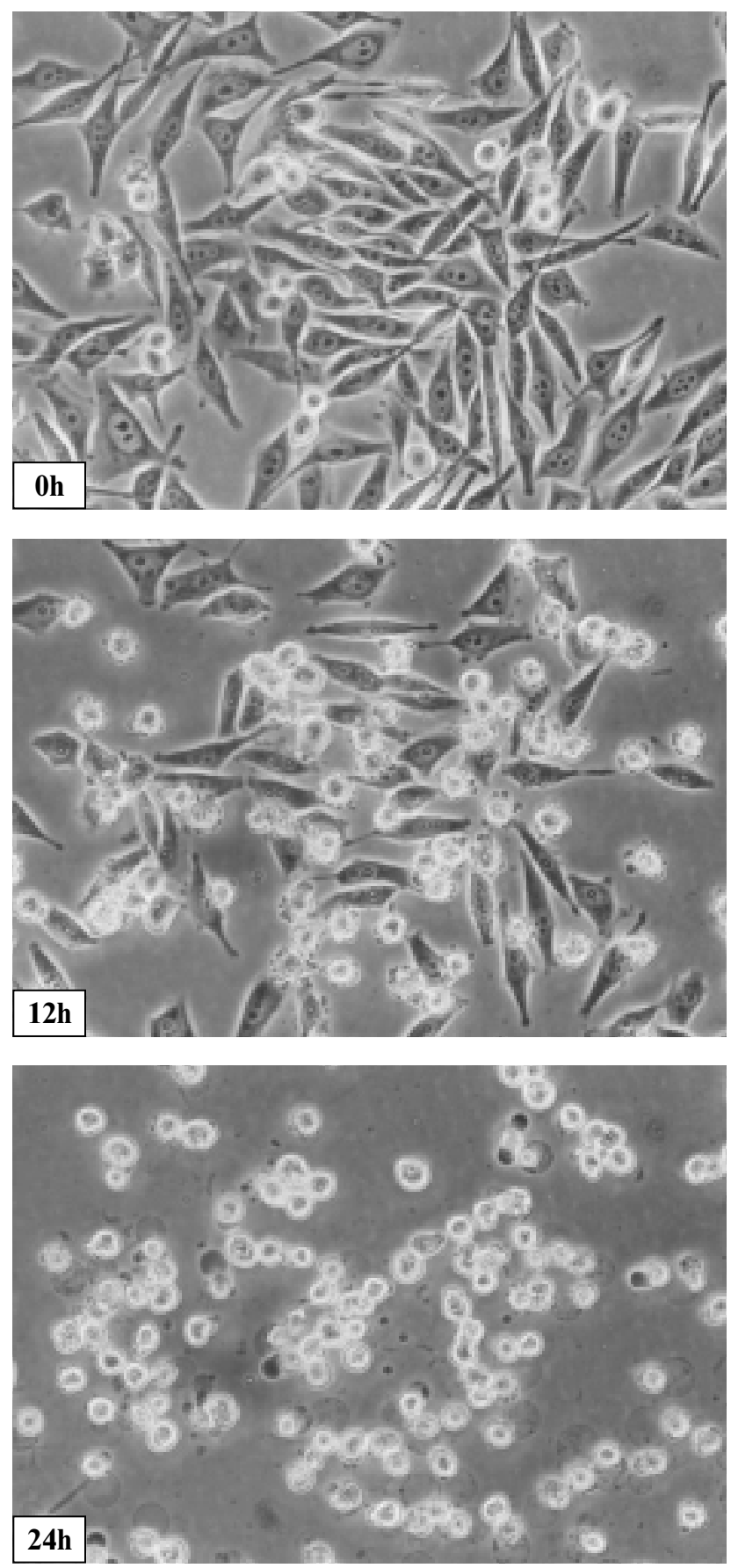

Fig. 1A: Dynamic behavior of Hep2 cells treated with potassium chromate at concentration $150 \mu \mathrm{g} / \mathrm{ml}$. Photographs were taken 0,12 and 24 hours after starting the experiment. Phase contrast $400 \mathrm{x}$, Olympus IMT-2. in TE buffer containing $10 \mathrm{mmol} / \mathrm{l}$ Tris- $\mathrm{HCl}$ and 1 mmol/1 EDTA ( $\mathrm{pH}$ 8.0) and separated by horizontal gel electrophoresis on $2 \%$ agarose gel stained with ethidium bromide. Running time 2 hours at $50 \mathrm{~V}$. The assay was carried out simultaneously for both cell lines - Hep2 and HL-60.
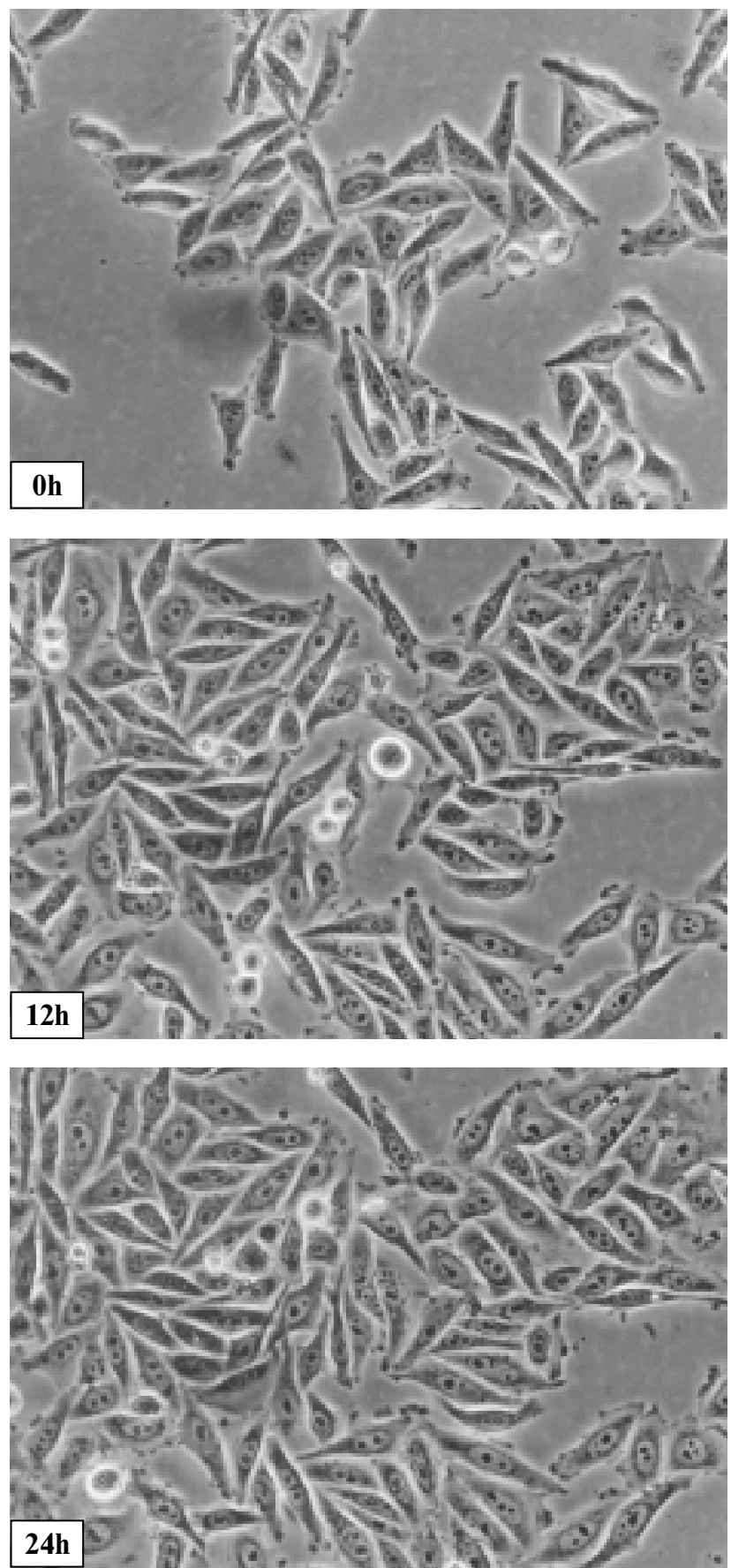

Fig. 1B: Dynamic behavior of Hep2 cells - control culture. Photographs were taken 0,12 and 24 hours after starting the experiment. Phase contrast $400 \mathrm{x}$, Olympus IMT-2. 


\section{Statistics}

Statistical analysis was carried out with a statistical program GraphPad Prism. We used one-way Anova test with posttests Dunnet's or Bonferroni. Results were compared with control samples, and means were considered significant if $\mathrm{P}<0.01$.

\section{Results}

Time-lapse video microscopy. The first changes in the appearance of the exposed cells were observable as early as the 6-8 hours after the beginning of the treatment. These included nuclear changes, in particular a nucleolar brightening. Some cells assumed rounded shape and formed protrusions on its surface, a process called blebbing. The time-lapse sequence (not presented here) proved blebbing to be an hours lasting "cell dance," consisting of rhythmically repeated cell contractions and relaxations. This dance gradually affected the entire observed cell population. After 16 - 18 hours of the treatment, all the cells entered either the blebbing stage or remained motionless. In addition, many showed the features of so called secondary necrosis, that is, a cloudy cytoplasm release and the absence of any life-characteristic behavior. The 24 hours-lasting treatment then brought no more changes to the cell appearance. Unlike typical necrosis, observed after a treatment of the same cells with different compounds, there was no massive presence of dirt in the medium. The cell morphology is shown in Fig 1.

WST-1 assay. The results are shown in Fig. 2. After 8 hours treatment, the Hep-2 cells metabolic activity measured by the cleavage of tetrazolium salt WST-1 by mitochondrial succinate dehydrogenase was significantly decreased when compared to the control cells, with 24 hours lasting treatment reducing it almost completely.

Selective nuclear-fragmentation staining. Cell nucleus apoptotic changes, such as chromatin condensation and marginalization, first appeared 8 hours after exposure to 150 $\mu \mathrm{g} / \mathrm{ml}$ potassium chromate (Fig. 3). Within 12-16 hours, all the cells displayed them and simultaneously began to show features of nucleus decomposition. The cells exposed to the tested substance for 24 hours or more were heavily damaged, with their nucleus content released (Fig. 3).
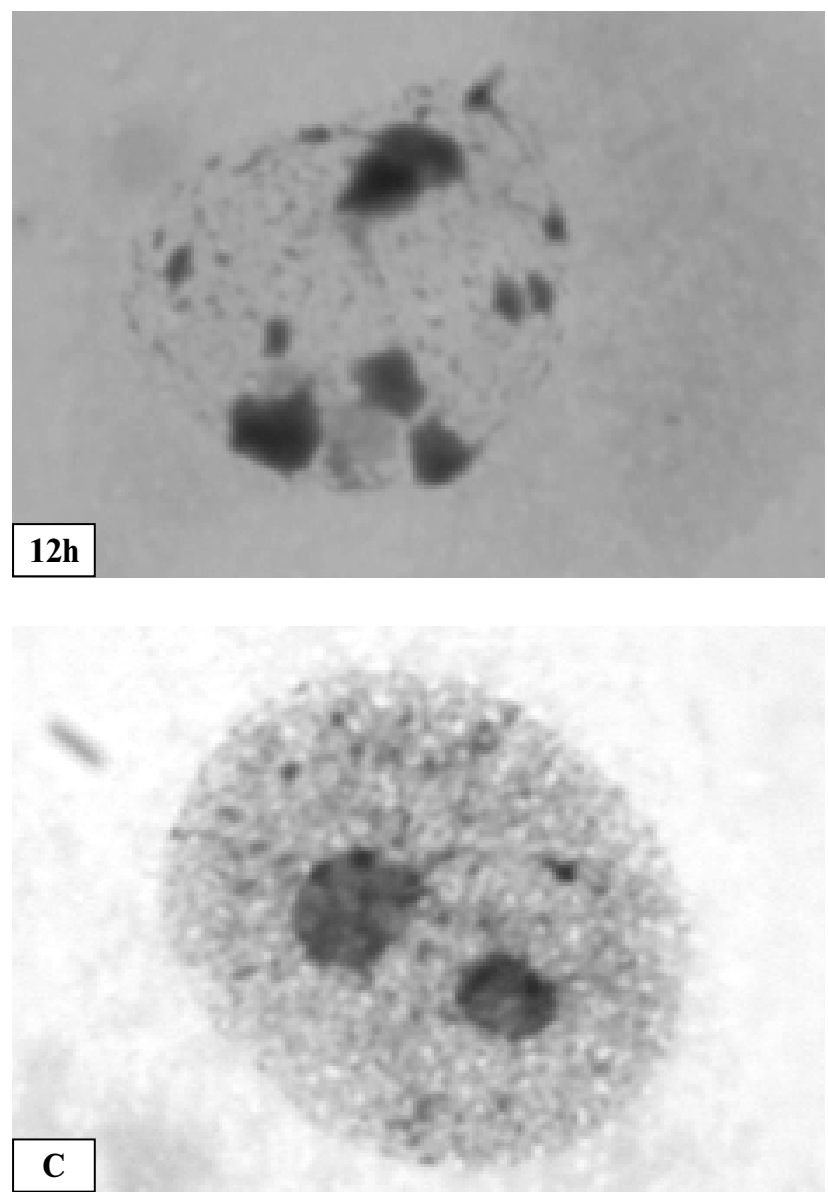
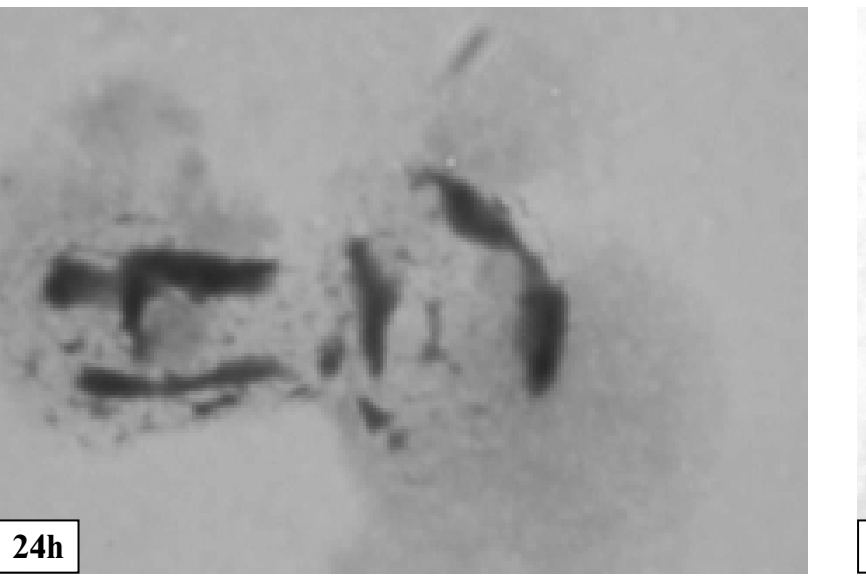

Fig. 3: Selective nuclear-fragmentation staining of Hep2 cells with a Giemsa solution following the treatment with $150 \mu \mathrm{g} / \mathrm{ml}$ potassium chromate. Photograps were taken at time intervals 8, 12, and 24 hours after starting the experiment. C stands for the control cells. Bright field $1000 \mathrm{x}$, Nikon COOLPIX 950. 


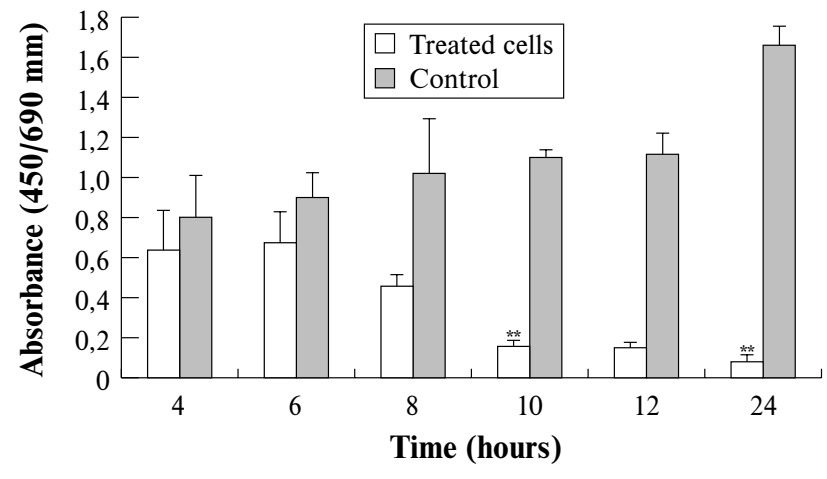

Fig. 2: The effect of potassium chromate at concentration $150 \mu \mathrm{g} / \mathrm{ml}$ on viability of Hep 2 cells assessed by measurement of cells metabolic activity using WST-1 assay. The significant decrease in viability was observed at 8 hours of the treatment, and after 24 hours there was almost no measurable activity. Presented values are the mean \pm SD of at least three different experiments. ${ }^{* *} \mathrm{P}<0.01$, using one wayAnova test, with post tests Dunnet's or Bonferroni.

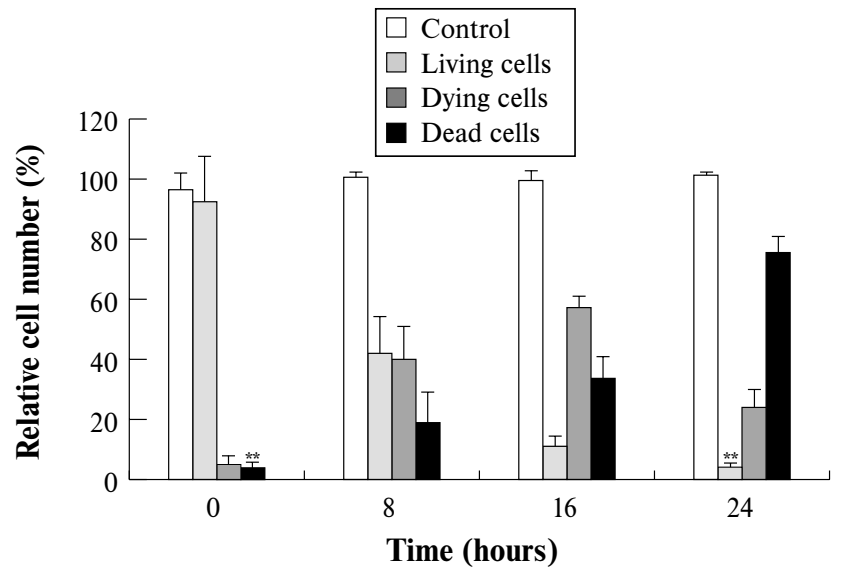

Fig. 4: Quantitation of Hep2 cells viability and apoptotic index by acridine orange/ethidium bromide uptake following the treatment with $150 \mu \mathrm{g} / \mathrm{ml}$ potassium chromate. Cells were counted in 100 visual fields, with minimal counted cell number 500. Living, dead and dying (apoptotic) cells were distinguished by their selective staining (living and apoptotic - green, dead - orange). Presented data are the mean $\pm \mathrm{SD}$ of at least three different experiments. $* * \mathrm{P}<$ 0.01 compared with control culture, using one way-Anova test, with post tests Dunnet's or Bonferroni.

Photograps were not software-processed.

Quantitation of cell viability and apoptotic index by acridine orange/ethidium bromide uptake. This method is based on the difference between normal and apoptotic cells nuclei (they fluoresce bright green-yellow) and dead cells nuclei (they fluoresce orange). The results shown in Fig. 4 show varying proportions of living, apoptotic and dead cells in different time intervals. The major increase in the number of apoptotic cells was observed 8 hours after the beginning of the treatment, with plateau observed in $16^{\text {th }}$ hour. After 24 hours, there were almost neither living nor apoptotic cells in the observed specimens (Fig. 4). These results correlate with those obtained by the morphological analyses.

DNA fragmentation assay. The appearance of DNA from Hep 2 cells treated with $150 \mu \mathrm{g} / \mathrm{ml}$ potassium chromate is shown in Fig. 5. Fragmentation which was detectable after the 8 and 12 hours treatment was not observed after 16 and 24 hours. The position and the size of the observed DNA fragments did not fully correspond to the typical DNA ladder.

The appearance of DNA from HL-60 cells treated with $150 \mu \mathrm{g} / \mathrm{ml}$ potassium chromate is shown in Fig. 6. Faint fragmentation was detectable after the 6 hour treatment, with the $180 \mathrm{bp}$ fragments clearly visible even after 24 hours.

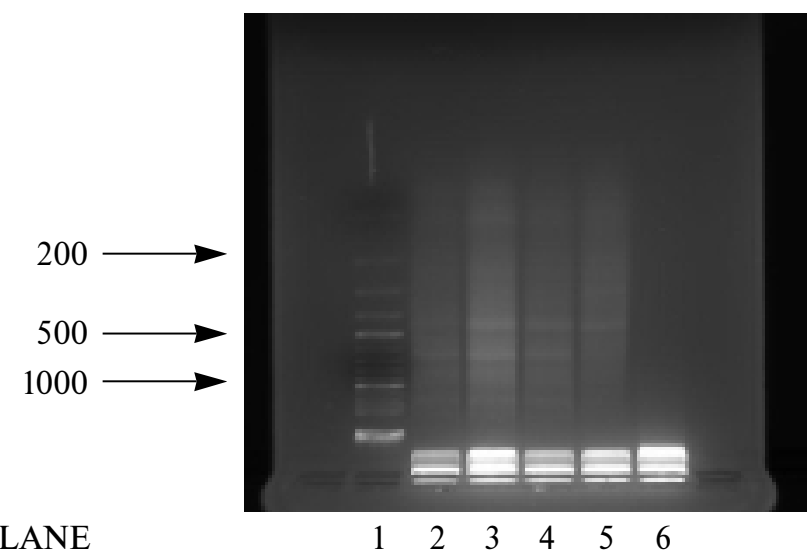

Fig. 5: The appearance of DNA from Hep2 cells treated with $150 \mu \mathrm{g} / \mathrm{ml}$ potassium chromate at time intervals 6 (lane 2), 8 (lane 3), 12 (lane 4), and 24 hours (lane 5). Size marker is shown in lane 1 , negative control in lane 6 .

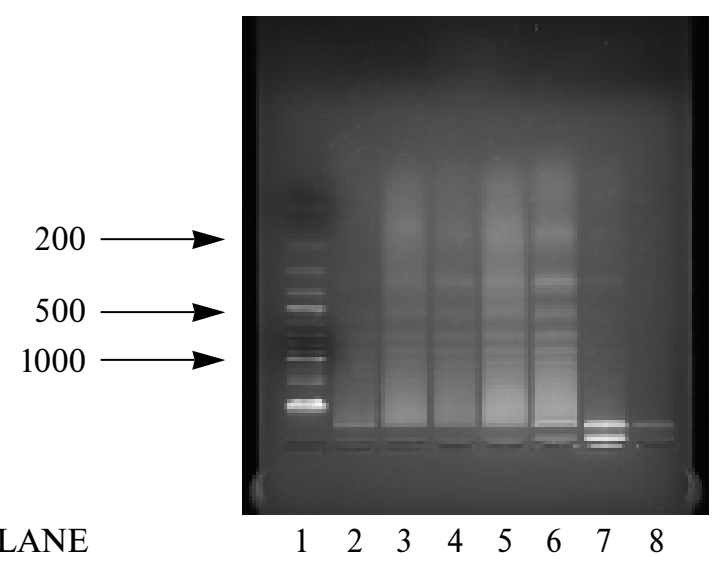

Fig. 6: The appearance of DNA from HL-60 cells treated with $150 \mu \mathrm{g} / \mathrm{ml}$ potassium chromate at time intervals 6 (lane 2), 8 (lane 3), 12 (lane 4), 16 (lane 5), 24 (lane 6), and 48 hours (lane 7). Size marker is shown in lane 1, negative control in lane 8 . 


\section{Discussion}

Some hexavalent chromium compounds are nowadays extensively studied due to their suspected or proven influence on the development of cancer, or, their ability to induce apoptosis. This is especially true in the case of lead chromate compounds, most of which are, in terms of their effect, associated with occupational lung cancer (13). The vast array of mechanisms whereby lead chromate instigates its cytotoxic, carcinogenic, and proapoptotic potential was reported by leading scientists in well-established journals, and is more thoroughly discussed at scientific congresses. On the other hand, however extensive our knowledge about the effect of the particular chromium compound on the particular cell type may be, we are still at pain to determine the exact dynamic sequence of steps leading to apoptosis or its suppression (13). This dynamic aspect and patterns of chromium induced apoptosis are not very often studied and discussed, apparently because of the relative complexity and time-consuming nature of the experiments.

In our study, we used potassium chromate at concentration $150 \mu \mathrm{g} / \mathrm{ml}$ for the induction of apoptosis in Hep2 cells. The tests we used for cell death detection belong to the standard battery of techniques employed by many scientists $(5,13)$. According to our results, the first observable dynamic morphologic changes (nucleolar brightening) in Hep 2 cells exposed to potassium chromate appear very early - during the first two hours of exposure (Fig.1). This is, to our knowledge, the initial signal of some irreversible changes in nucleolus (4). The cells ceased their proliferation, and at 6 hours of treatment the first apoptotic figures appeared. The maximum apoptotic activity was seen at the time interval 8-12 hours, and this period also was marked by significant decrease in the same cell metabolic activities as well as their membrane damage (Fig. 2,4). Nuclear architecture underwent similar changes, with profound changes observed after 8 hours of treatment (Fig. 3).

Our observed result agree with other published papers $(3,5,13)$, while only DNA analysis yielded different results, with the DNA fragments being not multiples of $180 \mathrm{bp}$ (Fig. 5). Still, some DNA changes pointing at fragmentation were observed, especially when we compare it with electrophoresis of DNA from necrotic cells.

This discrepancy in results may have several explanations. One feasible is that some epithelial cells, upon their apoptosis, lack the typical laddering pattern, which has already been reported by some scientists (6). Moreover, if the typical DNA fragmentation occurred in one specific moment, we could not possibly capture it despite the DNA sampling in various time intervals. Based on the results of time-lapse videomicroscopy as well as other dynamic techniques, this hypothesis may appear at least partially satisfying because, obviously, potassium chromate did not synchronize an entry of all the cells into apoptosis, i.e. in a given time interval only some cells appeared to undergo apoptosis, whereas, the rest had already been dead or were still living. Still, it is generally believed that DNA laddering is almost universal marker of apoptosis and some objections might be raised to the above conclusions. Therefore, to verify if potassium chromate can induce typical apoptosis, we used HL-60 cell line, which is very commonly used for apoptotic studies $(1,9,16)$. Fig. 6 shows the typical laddering, first visible at six hours of treatment and detectable even after 24 hours of treatment with potassium chromate. This clearly verifies our conclusions.

Thus, while discussing the effects of potassium chromate on various cell types and models, we must be aware of the fact that different cells may respond to it in different ways. This goes especially for the seemingly opposing results we report here with the results of a German group which published the data suggesting necrotic death caused by potassium chromate at doses $0-1000 \mu \mathrm{mol} / 1$ in human hepatocytes HepG 2 and in the cell line obtained from proximal kidney tubules of opossum (7). Therefore it appears that some chromium compounds may provoke in different cell lines varying, often confusing responses, prompting the need for more experimental studies, employing a lot of different detection techniques.

\section{Conclusions}

Potassium chromate at dose $150 \mu \mathrm{mol} / 1$ induces apoptosis - like cell death in Hep 2 cells. The earliest apoptotic features are observable with all the employed techniques at 6 hours after the beginning of the treatment, with a plateau reached between 8-12 hour. Despite their marked apoptotic behavior, Hep2 cells do not show typical laddering pattern, which may have various reasons.

In our opinion, various techniques and approaches are necessary for dynamic studies into xenobiotic-induced apoptosis, particularly those techniques which are aimed at the earliest apoptotic stages.

\section{References}

1. Bagchi D, Joshi SS, Bagchi M, Balmoori J, Benner EJ, Kuszynski CA, Stohs SJ Cadmium- and chromium-induced oxidative stress, DNA damage, and apoptotic cell death in cultured human chronic myelogenous leukemic K562 cells, promyelocytic leukemic HL-60 cells, and normal human peripheral blood mononuclear cells. J Biochem Mol Toxicol 2000;14:33-41.

2. Barry MA, Behnke CA, and Eastman A. Activation of programmed cell death (Apoptosis) by cisplatin, other anticancer drugs, toxins, and hyperthermia. Biochem Pharmacol 1990;40:2353-62.

3. Blakenship LJ, Manning FCR, Orenstein JM, Patierno SR. Apoptosis is the mode of cell death caused by carcinogenic chromium. Toxicol Appl Pharm 1994; 126:75-83.

4. Bosman FT. The nuclear matrix in pathology. Wirchows Archiv - An International Journal of Pathology 1999;435:391-9.

5. Bridgewater LC, Manning FCR, Woo ES and Patierno SR. DNA polymerase arrest by adducted trivalent chromium. Mol Carcinog 1994;9 (3):122-3.

6. Cohen G, Sun X-M, Snowden RT, Dinsdale D, Skilleter DN. Key morphological features of apoptosis may occur in the absence of internucleosomal DNA fragmentation. Biochem J 1992;286:331-4.

7. Dartsch PC, Hildenbrand S, Kimmel R, Schmahl FW. Investigations on the nephrotoxicity and hepatotoxicity of trivalent and hexavalent chromium compounds. Int Arch Occup Environ Health 1998;71(Suppl.):40-5.

8. De Flora S, Bagnasco M, Zanucchi P. Genotoxicity of chromium compounds: a review. Mutat Res 1990;238:99-172.

9. Finucane DM, Waterhouse NJ, Amarante-Mendes GP, Cotter TG, Green DR. 
Collapse of the inner mitochondrial transmembrane potential is not required for apoptosis of HL-60 cells. Exp Cell Res 1999;251:166-74.

10. Kerr, JFR, and Harmon, BV. Definition and incidence of apoptosis: A historical perspective. In Tomei LD, and Cope FO, eds. Apoptosis: The Molecular Basis of Cell Death. New York: Cold Spring Harbor Press, Plainview, 1991:5-29

11. Methods in Cell Biology. Vol.46 Cell Death. (Schwartz, Osborne, eds) San Diego: Academic Press,1995:459.

12. Rudolf E. Přehled poznatků o toxicitě chromu. Acta Med (Hradec Králové) Suppl 1998;1:55-65.

13. Singh J, Carlisle, DL, Pritchard, DE, Patierno SR. Chromium-induced genotoxicity and apoptosis: Relationship to chromium carcinogenesis (Review). Oncol Rep 1998:5:1307-18.

14. Susa N, Ueno S, Furukawa Y, Michiba N, Minoura S. Induction of lipid peroxidation in mice by hexavalent chromium and its relation to the toxicity. Jpn J Vet Sci 1989;51:1103-10.

15. Terada K, Kaziro Y, Satoh T. Analysis of Ras-dependent signals that prevent caspase-3 activation and apoptosis induced by cytokine deprivation in hematopoietic cells. Biochemical and Biophysical Research Communication 2000;267:449-55

16. Witenberg B, Kletter Y, Kalir HH, Raviv Z, Fenig E, Nagler A, Halperin D, Fabian I. Ascorbic acid inhibits apoptosis induced by X irradiation in HL60 myeloid leukemia cells. Radiat Res 1999;152:468-78.

Submitted March 2000.

Accepted June 2000.

Mgr. Emil Rudolf,

Charles University in Prague,

Faculty of Medicine in Hradec Králové,

Department of Medical Biology and Genetics, Šimkova 870, 50001 Hradec Králové, Czech Republic. e-mail: rudolf@lfhk.cuni.cz 